\title{
CAMAROPHYLLUS RODWAYI (HYGROPHORACEAE), A REDISCOVERED FUNGUS
}

\author{
by Angie Monks and A.K. Mills \\ ( with one text-figure)
}

\begin{abstract}
Hygrophorus rodwayi Massee has been rediscovered and is redescribed. It has an irregular gill trama and consequently the new combination Camarophyllus rodwayi (Massee) Monks \& Mills is proposed.
\end{abstract}

Key Words: Camarophyllus rodwayi, fungus, Hygrophoraceae, Tasmania.

In BANKS, M.R. et al. (Eds), 1991 (31:iii): ASPECTS OF TASMANIAN BOTANY - A TRIBUTE TO WINIFRE

CURTIS.Roy. Soc. Tasm. Hobart:13-14. https://doi.org/10.26749/rstpp.124.2.13

\section{INTRODUCTION}

During a survey of Hygrophoraceae of Tasmania, reference was made to the Rodway collection of fungi in the Tasmanian Herbarium (HO). One collection (Rodway 137) is labelled "Hygrophorus rodwayi Mass. Co-type" and consists of a painting, plus brief description. A duplicate specimen of Rodway 137 was located at Royal Botanical Gardens, Kew (K). Now, some 90 years after its description by Massee (1899), further collections of this fungus have been made. These conform both to Massee's description and to the collections deposited in Hobart and Kew. However, the irregular gill trama and globose spores of the fungus place it in the genus Camarophyllus (Fr.) Kummer (Horak 1968), not Hygrophorus Fr., a closely related genus which has bilaterally divergent gill trama. The species is redescribed below from recent collections.

\section{TAXONOMY}

\section{Camarophyllus rodwayi (Massee) Monks \& Mills, comb.nov.}

Basionym: Hygrophorus rodwayi Massee, Bull. Misc. Int. Kew 1899: 178. "Tasmania. On the ground, Rodway 137 " (specimen and painting).

Holotype: Tasmania Rodway $137, \mathrm{~K}$ !

Isotype: Tasmania, ii.1898, Rodway 137, HO! (painting only).

\section{Description of Recent Collections}

Pileus 12-30 mm diameter, hemispherical to plane to slightly depressed, whitish to pale brown, usually pale brown at the disc (Kornerup \& Wanscher 1978, 5C4), paling to off-white or pale yellow (4A3) at the margin, dry, felty, margin entire, slightly inrolled in youth, sometimes cracking. Lamellae decurrent, thick, waxy, subdistant, white to pale yellow (4A3), interveined in larger specimens. Lamellulae of one, rarely two shorter lengths. Stipe $30-50 \mathrm{~mm}$ by $3-8 \mathrm{~mm}$, equal to tapering below, hollow to very loosely stuffed, whitish to pallid yellowish brown (5C4) especially towards the base,
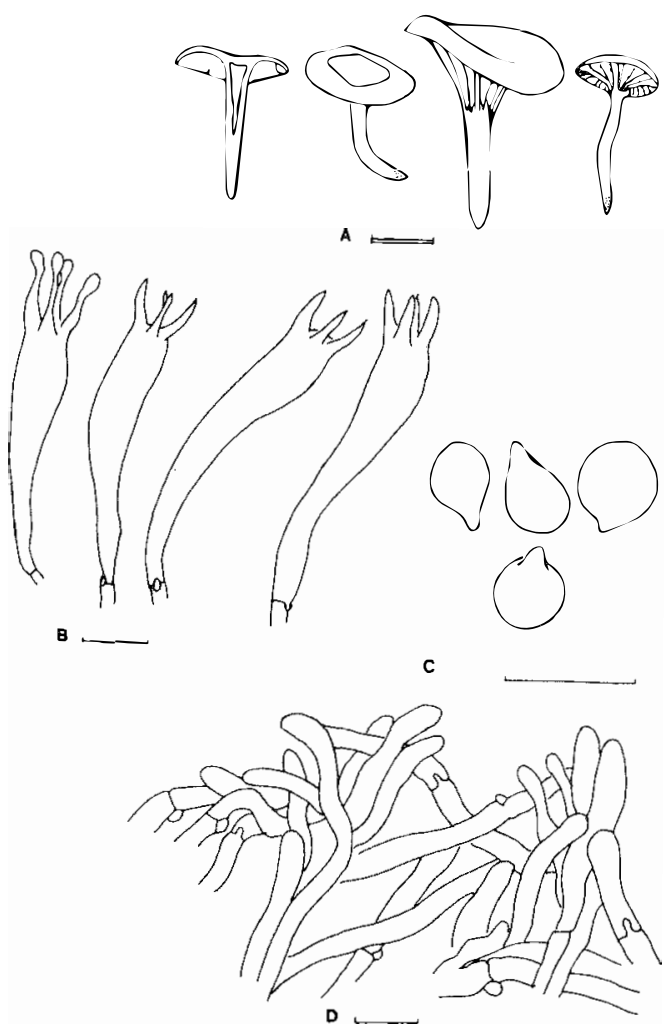

FIG. 1 - Camarophyllus rodwayi. (A) carpophores ( scale bar $=10 \mathrm{~mm}),(B)$ basidia,$(C)$ spores, $(D)$ vertical section of pileipellis (scale bar $=10 \mu \mathrm{m}$ ). 
glabrous, dry. Pileal context white. Spore print white. Spores 6-8 $845 \mu \mathrm{m}$ (mean $7.5 \times 5.4 \mu \mathrm{m})$, subglobose, hyaline, inamyloid, smooth. Basidia 40-54 (mean $45.6 \mu \mathrm{m}) \times 4-6 \mu \mathrm{m}, 4$-sterigmate. Cystidia absent. Pileipellis of suberect to repent, interwoven, very slightly gelatinised cylindrical hyphae, 3.75-5 $\mu \mathrm{m}$ diameter, containing cytoplasmic pigments. Subpileipellis of interwoven, cylindrical hyphae, 5-10 $\mu$ m diameter. Gill trama irregular, of cylindrical hyphae, $5.00-8.75 \mu \mathrm{m}$ diameter. Clamp connections present.

\section{Specimens Examined}

Tasmania: Collinsvale, v.1989, Monks 178 (HO); Smithton, 14.vi.1989, Monks 194 (HO); Little Florentine River, vii.1989, Monks 241 (HO); Mt Field, vii.1989, Monks 169 (HO).

\section{DISCUSSION}

The Hobart material comprises a painting only. The material from the Royal Botanical Gardens, Kew, is most likely the specimen examined by Massee and contains the only basidiome material extant from Rodway's collection. The recent collections match the Massee description, but examination of the type material reveals spores up to $10 \mu \mathrm{m}$ long and more elongate basidia $(60-70 \mu \mathrm{m})$. Other hyphal elements of the type and recent collections are in close agreement.
The type locality, Kingston, is now a suburban region of Hobart. All recent collections are from the wetter regions of Tasmania (annual rainfall $1100 \mathrm{~mm}$ ). The fungus occurs on moss-covered soil in mature "mixed forest" (i.e. Eucalyptus spp./Atherosperma moschatum/ Nothofagus cunninghamii).

Camorophyllus rodwayi is distinguished from other Australian members of Hygrophoraceae by a combination of brown to pale yellowish, off-white, pileus colour and decurrent to deeply decurrent gills.

\section{ACKNOWLEDGEMENTS}

The authors wish to thank Drs E. Horak and G. Kantvilas for critical appraisal of the manuscript.

\section{REFERENCES}

Horak, E., 1968: Synopsis Generum Agaricalium. Beitr. Kryptog. Fl. Schweiz. 13: 141-143.

KorneruP, A. \& WANSCHER, J.H., 1978: METHUEN HANDBOOK OF COLOUR, 3rd edn, Cox and Wyman Ltd, Norfolk.

MASSEE, G., 1899: Fungi exotici II. Bull. Misc. Inf. Kew 1899: 178.

(accepted 10 August 1990)
A. Monks and A.K. Mills
Department of Plant Science, University of Tasmania, GPO Box 252C, Hobart, Tasmania, Australia 7001 